\title{
フェーズフィールドモデルによる析出相内部の 応力変化と残留応力のシミュレーション*
}

\author{
上原拓 也*1, 辻 野 貴 洋*2
}

\section{Simulations on the Stress Evolution and Residual Stress in Precipitated Phase by Using the Phase Field Model}

\author{
Takuya UEHARA*3 and Takahiro TSUJINO \\ ${ }^{* 3}$ Department of Computational Science and Engineering, Nagoya University, \\ Furo-cho, Chikusa-ku, Nagoya-shi, Aichi, 464-8603 Japan
}

\begin{abstract}
Microstructure formation and the stress evolution in the microstructure is simulated based on the coupling equations among the phase, temperature and stress/strain. Grain growth processes from some nuclei of the precipitated phase are simulated under three different conditions. Assuming volumetric dilatation in transformation to the precipitated phase, tensile and compressive stresses are generated at the interfacial region, and the distribution changes as the grain grows. The elastoplastic model gives the residual stress distribution in the material, which is not able to be obtained by the elastic calculation. A grain-growth model with regularly disposed four nuclei demonstrates creation of residual stress zone along the grain boundaries. Another model with randomly distributed nuclei also gives the residual stress distribution along the grain boundaries, in which dependence of the stress on the size and shape are observed.
\end{abstract}

Key Words: Numerical Analysis, Thermal Stress, Residual Stress, Phase Field Model, Phase Transformation, Coupling Effects, Finite Element Analysis

\section{1. 緒言}

材料の機械的, 力学的特性は, その微視的な内部構 造に大きく影響される. 特に, 近年の工学デバイスの 微小化に伴い, 従来は巨視的に一様かつ均質であり, 等方的な材料で構成されているとみなすことの多かっ た金属材料についても, その内部組織や内部構造の影 響が無視できなくなっている. その中でも, 結晶粒ス ケールとなる数 $\mu \mathrm{m}$ レベルの現象となると, 結晶粒の 形状, 分布とともに, 各結晶粒内に存在する残留応力 の存在が機械的な特性に重大な影響をもたらす.この ような微視組織内の残留応力の評価には, 凝固, 熱処 理, 再結晶化などの過程において, 結晶粒の成長とそ れに伴う応力変化を, 連成しながら同時に解析するこ とが必要となる. このような過程の数值解析手法とし ては, Johnson-Mehl-Avrami などの変態速度式と連続 体力学を連成した, 井上らによる変態・熱・力学的手 法 $^{(1)(2)}$ があるが，そこでは変態は体積分率 $\xi$ を用いて 表現されているため, 界面の移動や結晶粒形成を直接

* 原稿受付 2005 年 6 月 16 日.

*1 正員, 名古屋大学大学院工学研究科 (- 464-8603 名古屋市 千種区不老町).

*2 京都大学大学院エネルギー科学研究科 [現：新日本製鐵(株) (更671-1188 姫路市広畑区富土町 1)].

E-mail : uehara@ mech.nagoya-u.ac.jp
解析することはできない．

これに対し，フェーズフィールドモデルを用いると， デンドライトをはじめ, ファセットや多結晶組織を含 む様々な微視組織形成のシミュレーションを行うこと ができる ${ }^{(3)-(6)}$. しかし, そこでは相変態に伴う㐫力変 化の解析を行った例はほとんどなく, 組織内部の応力 や残留応力評価の解析には用いられていない. そこで, 著者らはこれまでに, 簡略化したモデルを用いて凝固 過程における弾性応力変化の解析を行ったが ${ }^{(7)(8)}$, さ らに本研究では, フェーズフィールドモデルによって 相変態を表現し, 温度, 応力を連成させることによっ て, 微視組織形成過程における応力変化と残留応力の 解析を行うことを目的としている． 前報 ${ }^{(9)}$ では，相変 態と, 温度, 応力を連成させたフェーズフィールド解 析の基礎式の定式化について報告したが，本報では， その基礎式に基づく数值解析について報告する.

\section{2. 基 礎 式}

基礎式の定式化については, 前報 ${ }^{(9)} て ゙$ 述べた通りで あり，ここでは，実際に用いる基礎式のみを示す。 
Table 1 Applied parameters for simulations.

\begin{tabular}{|c|c||c|c|c|c|c|c|}
\hline$m$ & $2.5 \times 10^{5}$ & $a, \mathrm{~m}^{4}$ & 10 & $b, \mathrm{~m}^{3} / \mathrm{J}$ & $5.0 \times 10^{-5}$ & $T_{\mathrm{m}}, \mathrm{K}$ & 400 \\
\hline$\rho, \mathrm{kg} / \mathrm{m}^{3}$ & $1.0 \times 10^{3}$ & $c, \mathrm{~J} /(\mathrm{kg} \mathrm{K})$ & $5.0 \times 10^{2}$ & $k, \mathrm{~W} /(\mathrm{m} \mathrm{K})$ & 150 & $L, \mathrm{~J} / \mathrm{m}^{3}$ & $3.0 \times 10^{3}$ \\
\hline$h, \mathrm{~W} /\left(\mathrm{m}^{2} \mathrm{~K}\right)$ & $1.0 \times 10^{4}$ & $T_{\mathrm{w}}, \mathrm{K}$ & 300 & $\Delta x, \mathrm{~m}$ & $1.0 \times 10^{-2}$ & $\Delta t, \mathrm{~s}$ & $1.0 \times 10^{-2}$ \\
\hline$E, \mathrm{GPa}$ & 200 & $\nu$ & 0.3 & $\sigma_{\mathrm{y}}, \mathrm{MPa}$ & 250 & $H^{\prime}, \mathrm{MPa}$ & 250 \\
\hline$\alpha, 1 / \mathrm{K}$ & $5.0 \times 10^{-6}$ & $\beta$ & $1.5 \times 10^{-3}$ & $n_{1}, \mathrm{MPa}^{-1}$ & $1.0 \times 10^{-2}$ & $n_{2}, \mathrm{MPa}^{-2}$ & $1.0 \times 10^{-5}$ \\
\hline
\end{tabular}

Table 2 Boundary and initial conditions for three simulation cases.

\begin{tabular}{|c|c|c|c|c|}
\hline Case & Thermal B.C. & Mechanical B.C. & Initial seed(s) & Init. Temp. \\
\hline \hline Case 1 & b1, b4: Adiab., b2, b3: Conv. & b1: $y$-fix, b2, b3: Free, b4: $x$-fix & Corner C & $400 \mathrm{~K}$ \\
\hline Case 2 & b1-b4: Conv. & b1-b4: Fixed & Corner A-D & $300 \mathrm{~K}$ \\
\hline Case 3 & b1-b4: Conv. & b1-b4: Fixed & Corner A-D \& 5 in bulk & $300 \mathrm{~K}$ \\
\hline
\end{tabular}

フェーズフィールド方程式 :

$$
m \dot{\phi}=a \nabla^{2} \phi+\phi(1-\phi)\left[\phi-\frac{1}{2}+M\left(\phi, T, \sigma_{i j}\right)\right]
$$

ただし，

$$
\begin{gathered}
M\left(\phi, T, \sigma_{i j}\right)=b \phi(1-\phi)\left(L \frac{T_{\mathrm{m}}-T}{T_{\mathrm{m}}}+f\left(\sigma_{i j}\right)\right), \\
f\left(\sigma_{i j}\right)=n_{1} \sigma_{k k}+n_{2} \sigma_{i j} \sigma_{i j}
\end{gathered}
$$

熱伝導方程式 :

$$
\rho c \dot{T}=k \nabla^{2} T+30 L \phi^{2}(1-\phi)^{2} \dot{\phi}-T \alpha \delta_{i j} \dot{\sigma}_{i j}+\sigma_{i j} \dot{\varepsilon}_{i j}^{\mathrm{p}}
$$

応力ーひずみ関係式 :

$$
\begin{aligned}
\dot{\varepsilon}_{i j}= & \frac{1+\nu}{E} \dot{\sigma}_{i j}-\frac{\nu}{E} \dot{\sigma}_{k k} \delta_{i j}+\dot{\varepsilon}_{i j}^{\mathrm{p}} \\
& +\alpha \dot{T} \delta_{i j}+30 \beta \phi^{2}(1-\phi)^{2} \dot{\phi} \delta_{i j}
\end{aligned}
$$

ここで, $m, a$ および $b$ は界面幅や界面エネルギーの 影響を表すフェーズフィールドパラメータ, $f\left(\sigma_{i j}\right)$ は 相変態の応力依存性を表す関数であり, $n_{1}, n_{2}$ は適当 なパラメータである. また, $\rho, c, k, L, T_{\mathrm{m}}$ はそれぞれ， 密度, 比熱, 熱伝導率, 潜熱, 変態温度, $\sigma_{i j}, \varepsilon_{i j}, \varepsilon_{i j}^{\mathrm{p}}$ はそれぞれ, 応力, ひずみ, 塑性ひずみ, $E, \nu, \alpha, \beta$ はそれぞれ, ヤング率, ポアソン比, 線膨張係数, 変 態膨張係数である．塑性ひずみにしては，降伏条件に はMises の条件, 硬化則には移動硬化則を用いた構成 式を用いる.

\section{3. 計算モデルと条件}

前節に述べた基礎式に基づき, 温度変化に伴う結晶 成長シミュレーションを行う。計算に用いるパラメー タの值は表 1 に示した通りである. ただし, $h, T_{\mathrm{w}}$ は 後述する熱伝達境界条件を与えるときの熱伝達係数お よび周辺温度, $\sigma_{\mathrm{y}}, H^{\prime}$ は弾塑性解析を行うときの初期

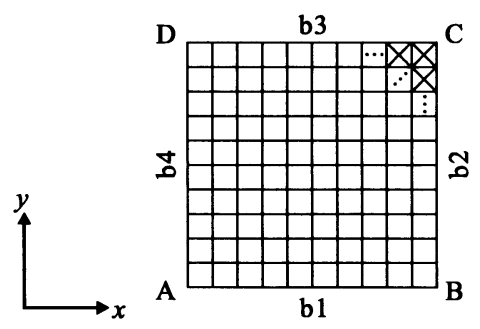

Fig. 1 Illustration of the simulation model and mesh division with notations of apices A-D and boundaries b1-b4.

降伏応力および硬化係数, $\Delta x, \Delta t$ は有限要素解析に おける要素サイズの基準および時間刻みである.これ らの值は，特定の材料を想定した值ではなく，変態一 熱一応力の連成効果が明確に現れるように設定した仮 想的な材料定数である.これらの值を用い，図 1 に示 したような 2 次元の正方形領域に対し, 表 2 に示した Case 1-3 の 3 種類の条件の下で, 有限要素法による数 值解析を行う. 領域サイズは, 表 1 に示した $\Delta x$ を単 位として, Case 1, 2 については $30 \times 30$, Case 3 につ いては $80 \times 80$ とし，斜辺の長さが $\Delta x$ である直角二 等辺三角形を用いた要素分割を行う.また，初期条件 としては，モデル内全域が均一な母相 $(\phi=0)$ であると し, 温度は均一な初期温度, 応力は全域で 0 とする. 析出相の初期核については, 計算の第 1 ステップにお いて, 表 2 に示した位置に強制的に析出相への変態を 起こすことによって核を発生させる.

Case 1-3 の説明として, まず, Case 1 では, 正方形 領域の 1 つの角（図 1 のC) に核を直き,そこから成 長を起こす。このとき, 境界条件としては, 核を配置 した頂点を挟む 2 辺（図 1 の b2，b3）を熱伝達境界， 残る 2 辺を断熱境界とする. また力学的拘束としては, 

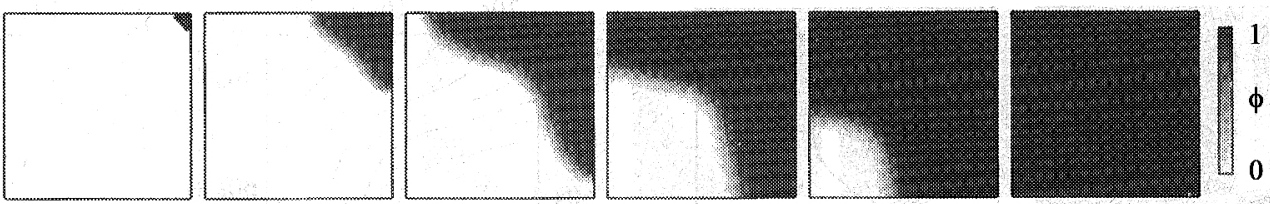

(a) Phase field
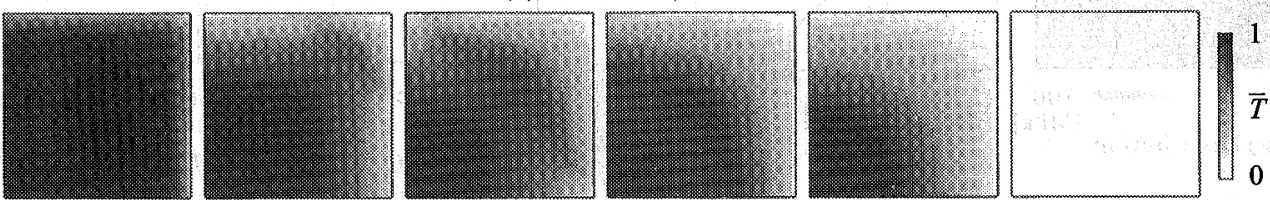

(b) Temperature
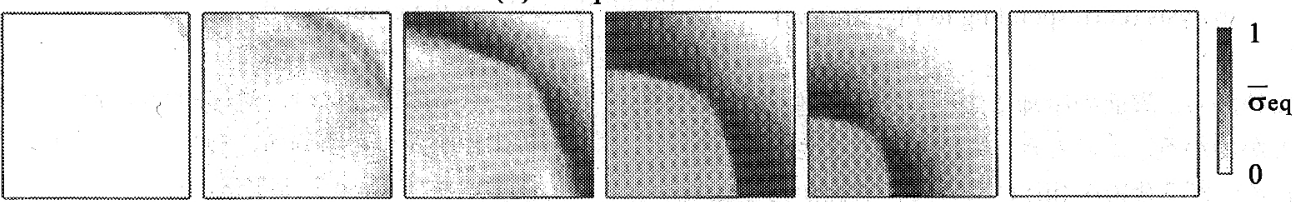

(c) Equivalent stress (Elastic calculation)

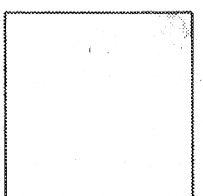

(i) $t=0.5 \mathrm{~s}$

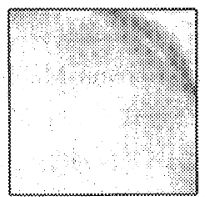

(ii) $t=10 \mathrm{~s}$

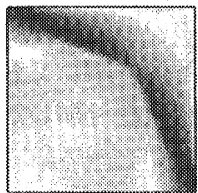

(iii) $t=20 \mathrm{~s}$

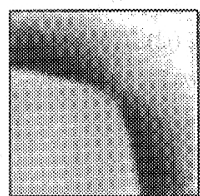

(iv) $t=40 \mathrm{~s}$

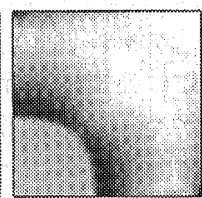

(v) $t=60 \mathrm{~s}$

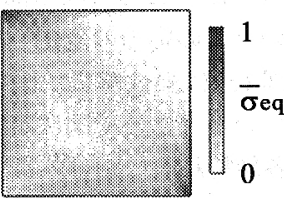

(vi) $t=200 \mathrm{~s}$

(d) Equivalent stress (Elasto-plastic calculation)

Fig. 2 Comparison between elastic and elasto-plastic calculation on the stress distribution due to phase transformation and thermal conduction (Case 1).

左側面（図 1 のb4 面）と下面（b1 面）をそれぞれ $x$, $y$ 方向に拘束し，残る 2 面は自由境界とする。これは， 表面から泠却をうける物体の角から，新しい相が析出 し，成長する過程を想定したモデルである.

Case 2 では，全周囲樊伝達境界とし，4つの角か。 ら自由に析出相が成長するモデルとする。ただし，力 学的には全周囲を固定する. Case 1 は，結晶成長モデ ルとしては,このモデルの $1 / 4$ 領域を解析したものに 相当するが，ここでは，全周囲を固定境界とすること によって，異なる核から成長した析出相が自由表面の 影響を受けずに界面を形成する過程を計算するもので ある。すなわち，内部で結晶粒界が形成される過程を 想定している．ただし，発生する潜熱によって温度が 著しく上昇することを防ぐため，周用は熱伝達境界と して設定している.

最後に Case 3 として，モデル内部に，ランダムに 核を配置し，複数の結晶粒から成る多結晶体の形成過 程のシミュレーションを行う，境界条件は Case 2 と同 様に, 全周围を固定, 熱伝達境界とする.

\section{4. 解析結果と考察}

\section{$4 \cdot 1$ 単一核からの成長 (Case 1)}

4.1.1 結晶成長と応力の変化 まず単一核から の成長解析を行い; 界面の移動と㐫力変化の様子を調 ぶる、比較のため, 弾性解析の夕索行った場合と, 弹 塑性解析を行った場合についての結果を示す。このと き, 弾性解析と弾塑性解析では, 忘力分布に相違が生 し，それがまた相変態に影響を与える.そこで, Case 1 では，主に相変態による応力変化について検証する ため, 相変態への応力の影響（式 $(2) \sigma f(\sigma)$ ) は無視 することとする

図 2 (a), (b) はそれぞれ，フェーズフィールドおよび 温度の時間変化を表したものである.ただし，温度は 初期温度と椧却温度で規格化した值で示している。こ れは弾性解析での結果であるが, $f(\sigma)$ を無視したこ とと，応力仕事による発熱量も大きくないことから， 弾塑性解析におるいも，同じ分布が得られることを確

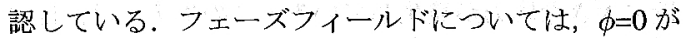
母相， $\phi=1$ が析出相を表しており，図の右上の角に置 


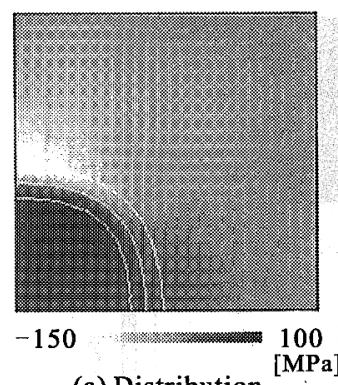

(a) Distribution

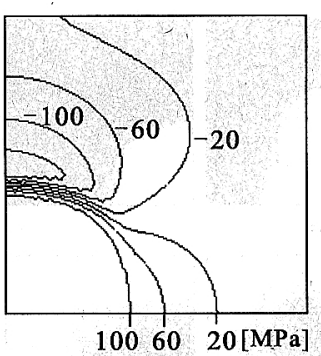

(b) Contour lines

Fig. 3 Stress in the $x$ direction at $t=30 \mathrm{~s}$ in elastic analysis (corresponding to Fig. 2(c)(v)).

かれた核から，表面の冷却に伴って変熊が進行してい ることがわかる。このとき，変態潜熱が発生して発熱 するため，図 2 (b)(ii), (iii)において，表面からやや内 部に入ったところに高温部分が生じている.

このときの応力の変化を表したのが図 2(c), (d) であ り, 図 (c) は弾性解析, 図 (d) 弾塑性解析の結果を 示している.ここで図に示した応力は, 相当応力であ り，各解析結果における最大值で規格化した值を示し ている．弾性解析，弾塑性解析のいずれの場合におい ても, 変態界面において大きな応力が発生し, 界面の 移動とともに，高い応力の領域が移動していることが わかる、ここで, 応力の符号を確認するために描いた のが図 3 であり，図 $2(\mathrm{c})(\mathrm{v})$ に示した弾性解析の $t=60$ $\mathrm{s}$ における応力の $x$ 方向成分を示している.また, 図 3 (a) は応力の分布に, $\phi=0.1,0.5,0.9$ 等值線を重㸚 たものであり，図3(b) は応力分布の等值線を表した ものである.この図に执いて，左側面上の分布をみる と，界面領域で応力が急激に変化し，応力の符号が反 転していることがわかる，すなわち，界面の接線方向 の応力成分は，界面領域で符号を反転している。これ は，母相から析出相への変態によって体積が膨張する ため, 界面の母相側に引張り，析出相側に圧縮の态力 が発生するためである. 力学的拘束としては，右側面 と上面を自由表面としているため，弾性変形のみを考 虑した場合には，自由に膨張し，最終的に全領域で変 態が完了し，温度分布もなくなると，図 2 (c)(vi)のよ らに無応力状態となる.これに対し，塑性を考慮した 解析では，変態途中に生じる応力が降伏㐫力を超え， 最終的には, 図 $2(\mathrm{~d})(\mathrm{vi})$ に示すように, 残留応力が生 じることがわかる。

なお，残留応力分布をみると，左上と右下の頂点付 近に大きな応力が発生している。このモデルは，自由 表面に囲まれる物体の1/4 領域をモデル化したもので

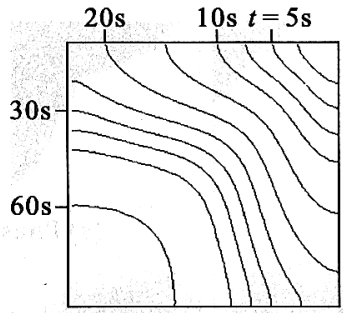

(a) Neglecting $f\left(\sigma_{i j}\right)$

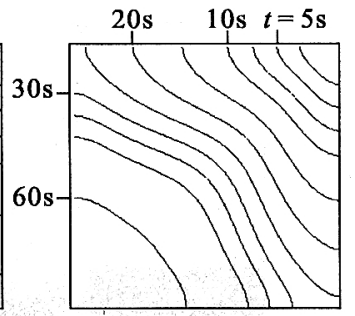

(b) Considering $f\left(\sigma_{i j}\right)$
Fig. 4 Effect of the function $f(\sigma)$, representing the stress-dependency on the phase transformation, on the grain growth.

ありここれらの部分には，対称的な位置から成長して きた析出相がぶつかる箇所に相当する。これについて は，次節に示す Case 2 で考察する.

-4.1.2 相変態の応力依存性 相変態に及ぼす忍 力の影響については，実験的にも知られており，数值 解析においても，Johnson-Mehl-Avrami の式に応力依 存項を付加した修正式 ${ }^{(10)}$ が用いられている。ここで は, その詳細については険討しないが，式 (3)に示し た $f(\sigma)$ によってその影響が表現されることを確認す る.モデルと境界条件は前項に示した計算と同じであ り, 弾塑性解析を行う。ただし，前項では $f(\sigma)$ を無 視した解析を行ったが，ここでは $f(\sigma)$ を考慮した解 析を行う。このときの計算結果を比較して示したのが 図 4 である。図中の等值線は，時刻 $t=5 \sim 60 \mathrm{~s}$ の界面

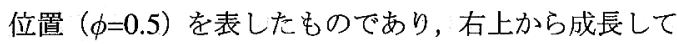
いく様子を表している，このとき，表面での界面位置 をみると， $f(\sigma)$ を無視した場合の図 (a)に比べ, $f(\sigma)$ を考虑した図 (b)では, 変態の進行がやや遅くなって いることがわかる.これに対し, 界面領域に沿った領 域のうち, 表面よりも応力の值が小さい対角線方向の 成長速度は，相対的にやや速くなり，結果的に界面の 曲率がなだらかになっていることがわかる.このこと から，界面に浻って応力分布が存在する場合，界面の 成長速度が一様でなくなり，界面形状に影響が現れる ことがわかる。

4.2 複数の核からの成長 (Case 2) 次に, 結晶 粒界の形成と応力分布の関係について考察するため, Case 2 として示した条件を与え，4つの核からの成長 によって結晶粒界が形成される過程の解析を行う。こ こでは， $f(\sigma)$ も考慮した弾塑性解析とし，すべての 連成を考慮した解析を行う。

このときの解析結果を図 5 に示す. 図 (a)-(c) はそ れぞれフェーズフィールド, 温度および相当応力分布 

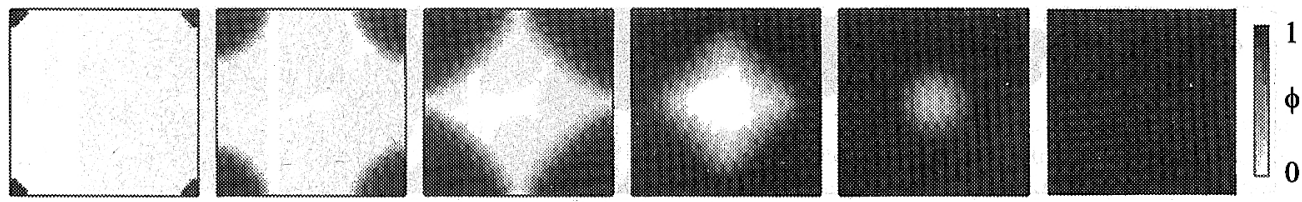

(a) Phase field
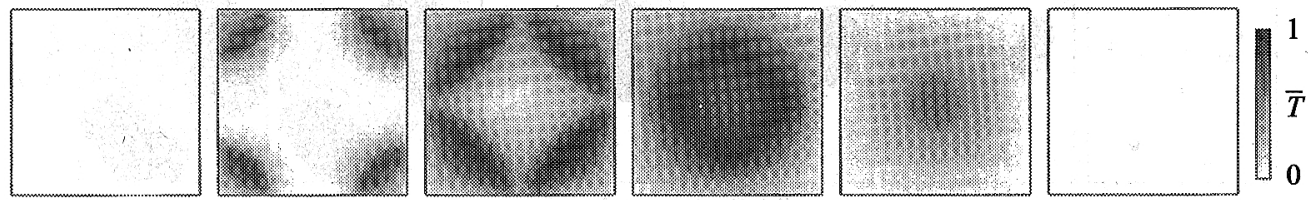

(b) Temperature
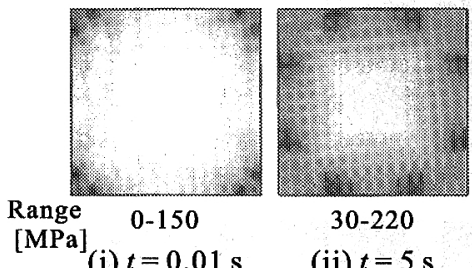

$30-220$

(ii) $t=5 \mathrm{~s}$

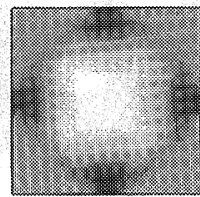

$100-240$

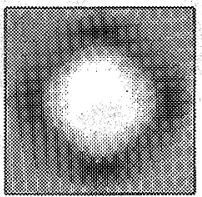

$160-270$

(iv) $t=20$

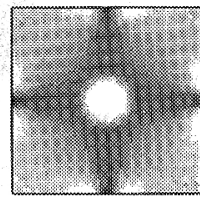

180-270

(v) $t=30 \mathrm{~s}$

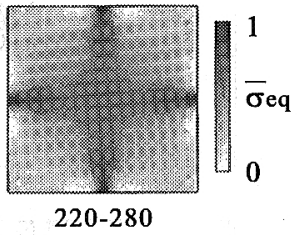

(vi) $t=200 \mathrm{~s}$

(c) Equivalent stress

Fig. 5 Stress evolution during grain growth from four nuclei, and residual stress distribution exhibiting cross shape (Case 2).

の変化を表している，ただし，温度については，解析 中の最大值と最小值で規格化した值を示しているが, 応力変化を示した図 (c) では，分布が明確になるよう に，各時刻における最大值と最小值で規格化した值を 用いて分布を示し，その最大值と最小值を図中に示し ている。

まず相変態に関しては，図 (a) に示すように，4つ の頂点に配置した核から析出相の成長が進行する。本 研究では，結晶粒成長の異方性は導入していないため, ほぼ円形に成長する。.Case 1 の場合と形状が異なる のは，初期温度が異なるためである。 やがて $t=10 \mathrm{~s}$ を 過ぎた頃に 4 つの成長領域が互いに衝突し，その後内 部へと変態が進行する．全領域で変態が完了すると, フェーズフィールドは一様に $\phi=1$ といら值を示すた め，図5においては結晶粒界は表示されないが，実際 には，異なる結晶核からの成長領域が衝突した後，結 晶粒界が形成されており，最終的には十字型の粒界か ら成る正方形の 4 つの結晶粒が得られている。 また， 温度変化については, Case 1 の場合と同様に，界面に おいて変態潜熱の発生が生じるが，表面から熱を逃が すことによって，最終的には均一な温度となる。

次に, 応力分布の変化をみると, 自由に成長が進行 する $t=10 \mathrm{~s}$ までの間は, Case 1 の場合と同様に, 界 面付近に大きな応力が生じる，ただし，Case 2 での境
界条件は，全周囲を固定条件としているため，界面領 域でも表面付近に，より大きな応力が生じている.こ の後, 析出相同士が衝突する $t=10 \mathrm{~s}$ 以降においては, 応力分布は著しく異なった様子を見せる.すなわち， 析出相が衝突して形成される粒界部分にきわめて大き な応力が発生する，その後，粒界が表面から内部に向 けて形成されるにつれて，粒界に沿って高い忍力の領 域が広がっていく.このとき， $t=10 \mathrm{~s}$ と $t=20 \mathrm{~s}$ の図を 比べると， $t=20 \mathrm{~s}$ においては，45 度方向となる母相 析出相の界面においても，大きな応力となっているこ とがわかる.これは, 粒界に囲まれて, 析出相の膨㖘 が強く拘束されるためであると考えられる，最終的に 変態が完了すると, 図 5 (c)(vi)に示すように, 十字型 に残留応力が生じていることがわかる。これは形成さ れた粒界に相当する領域であり，粒界に沿って高い残 留応力が発生していることを表している．なお，全体 的な平均忘力が増加するのは，周囲を拘束しているた め, 析出相への変態に伴う膨張が起こる分, 圧縮を受 けるためである。

4.3 多結晶体の形成過程 (Case 3) 最後に, 内 部にランダムに核を配置し，異なる形状と大きさをも つ結晶粒が形成される過程における応力変化のシミュ レーションを行った結果を図 6 に示す，図 6 (a)-(d) は それぞれ，フェーズフィールド，結晶粒番号，温度お 

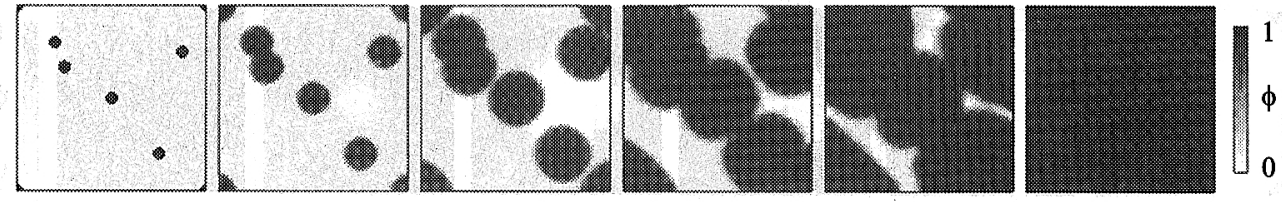

(a) Phase field
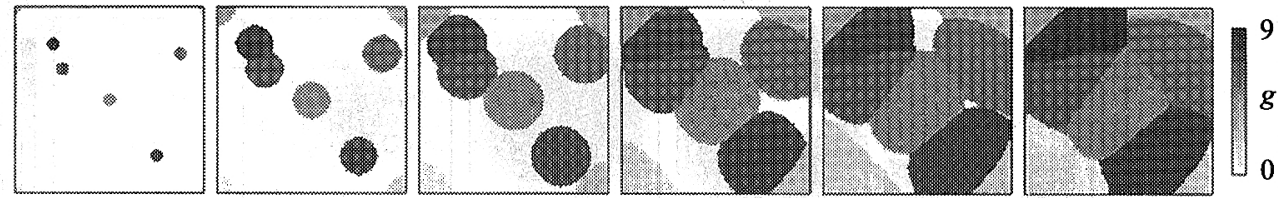

(b) Grain number
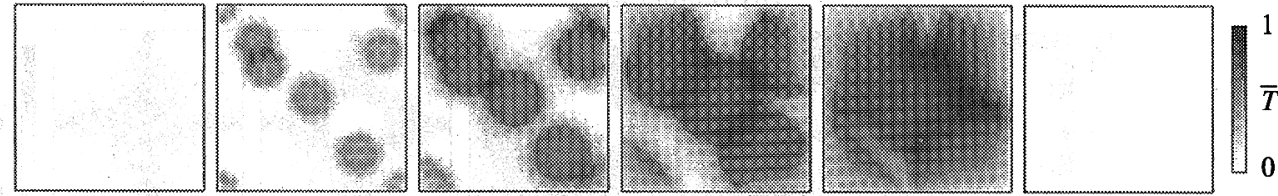

(c) Temperature
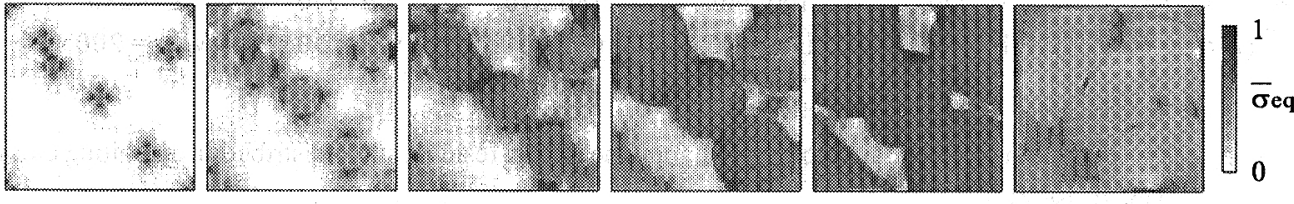

(i) $t=0.01 \mathrm{~s}$

(ii) $t=10 \mathrm{~s}$

(iii) $t=20 \mathrm{~s}$

(iv) $t=40 \mathrm{~s}$

(v) $t=60 \mathrm{~s}$

(vi) $t=200 \mathrm{~s}$

(d) Equivalent stress

Fig. 6 Polycrystal formation and stress evolution during grain growth from nine nuclei, exhibiting high stress region along grain boundaries (Case 3 ).

よび相当応力を示すここで；結晶粒番号とは，初期 配置として与えた核に，それぞれ異なる番号を与え， その後の変態で得られた析出相が, どの初期核から成 長したものかを識別する番号である。Fan, Chen ${ }^{(5)}$ Warren, Kobayashi, Carter ${ }^{(6)}$ は，このような異なる結 晶核から析出相が成長し，結晶粒界を形成した後の挙 動について, 結晶粒の回転や結晶方位の変化が生じる モデルを提案しているが，ここではそのモデルは導入 せず，析出相が衝突した部分が粒界となり，それ以上 の変化は起こらないものとする。これは，結晶粒の回 転や方位の変化には，原子スケールからの考察，また は本研究で明らかにしている応力分布が駆動力となっ た，より物理的なモデル化が必要であると考えるため， その関連があまり明確ではないモデルの利用は今回は 行わないという理由による。

図 6 (a), (b) から，これまでの計算結果と同様に結 晶核から析出相の成長が起こり，最終的には 9 つの結 晶粒からなる多結晶体が形成されることがわかる。温 度変化についても，これまでと同様に，変態潜熱によ る発熱で，析出相内の温度が上昇し，とくに界面での
温度が上昇する，応力の変化をみると, やはり変態の 進行とともに，界面付近において高い忘力が発生し， 形成される粒界に沿って大きな応力が生じた後，最終 的に，粒界に沿った残留応力が現れている.

変態途中の経過をたどると，図 6 (d)(ii)において， 領域内の左上付近で $2 つ の$ 結晶粒が衝突し，粒界が形 成されているが，このときの応力はそれほど大きくな く，残留応力分布を示可 (vi) においても，この粒界 における応力はほとんど識別できない程度である。こ れに対し，図 6 (d)(iv)，(v) あたりで形成された粒界付 近にはかなり大きな応力が発生し，残留応力でも粒界 部分が明確に現れる。これは，初期には結晶粒が小さ いため，変態膨張による体積変化量が比較的小さいこ と, 周囲の大部分が未変態領域であるため, 膨張に対 する拘束が小さいこと，後期になると変態完了領域が 大部分となり，拘束が大きくなっていることなどが要 因であると考えられる，また，結晶粒内にも忘力の分 布が見られ，3つの結晶粒の交わる 3 重点においては， より大きな応力が現れる傾向が見られる. 


\section{5. 結言}

本研究では, フェーズフィールドモデルを用いた相一 温度一応力の連成方程式を用いることによって，母相 から析出相が成長し, 微視組織が形成される過程にお ける忘力変化, および残留応力のシミュレーションを 行った. これによって, 界面付近に大きな応力が生じ ること, 粒界に沿って残留応力が現れること, 結晶粒 内や粒界の応力分布は, 結晶成長の過程に依存して複 雑な分布を示すことを示した. また, 従来の連続体モ デルによる変態・熱・学モデルでは不可能であった, 結晶粒の形成, 粒界および粒内の応力分布を得ること が可能であることを示した. 今後の課題としては, 結 晶粒の形状や大きさと応力分布の関係を明らかにする こと, 結晶方位に基づく異方性や, 粒界が形成された 後の挙動など, より微視的な構造や現象を取り込んだ フェーズフィールドモデルの導入を行うこと, 転位の 運動や粒界すべりなど, 塑性現象の本質的なモデル化 を行うことなどが挙げられる.

最後に, 本研究に関して有意義な助言を頂いた福山 大学 井上達雄教授に謝意を表する.

\section{文献}

(1) Inoue, T. et al., Description of Transformation Kinetics, Heat Conduction and Elastic-plastic Stresses in the Course of Quenching and Tempering of Some Steels, IngenieurArchiv, 50-5 (1981) 315-327.

(2) Inoue, T., Tanaka, K., Nagaki, S., Kotai Rikigaku to Souhentai no Kaiseki (Solid Mechanics and Analysis of Phase Transformation) (1995), Taiga Syuppan (in Japanese).
(3) Kobayashi, R., Modeling and Numerical Simulations of Dendritic Crystal Growth, Physica D, 63 (1993), 410423.

(4) Uehara, T. and Sekerka, R. F., Phase Field Simulations of Faceted Growth for Strong Anisotropy of Kinetic Coefficient, Journal of Crystal Growth, 254 (2003), 251264.

(5) Fan, D. and Chen, L.-Q., Computer Simulation of Grain Growth using a Continuum Field Model, Acta Materiaria, 45-2 (1997), 611-622.

(6) Warren, J. A., Kobayashi, R., Carter, W. C., Vectorvalued Phase Field Model for Crystallibation and Grain Boundary Formation, Physica D, 119 (1998), 415-423.

(7) Uehara, T. and Tsujino, T., Simulations on the Stress Evolution during Phase Transformation, Dail7kai Keisan Rikigaku Koenkai Koen Ronbunshu (Poceedings of the 17 th Computational Mechanics Conference) (2004), 313314 (in Japanese).

(8) Uehara, T. and Tsujino, T., Phase Field Simulation of Stress Evolution during Solidification, Journal of Crystal Growth, 275-1/2 (2005), 219-224.

(9) Uehara, T. and Tsujino, T., Formulation of Coupling Effects among Phase, Temperature and Stress by using the Phase Field Model, Nihon Kikai Gakkai Ronbunshu, A (Transactions of the Japan Society of Mechanical Engineers, Series A), 72-716 (2006), 438-444 (in Japanese).

(10) Wang, Z.-G. and Inoue, T., Analyses of Temperature, Structure and Stress during Quenching of Steel with Consideration for Stress Dependence of Transformation Kinetics, Zairyo (Journal of the Society of Materials Science, Japan), 32-360 (1983), 991-996 (in Japanese). 